\title{
Path Dependence and Local (Self-)Government Systems: A Comparison of three CEE Countries
}

\author{
DANIEL KLIMOVSKÝ, UROŠ PINTERIČ AND PETR JÜPTNER
}

\section{sciendo}

Politics in Central Europe (ISSN: 1801-3422)

Vol. 15, No. 2

DOI: 10.2478/pce-2019-0015

\begin{abstract}
Path dependence is a concept often used by scholars in fields such as economics, economic geography, political science, law and sociology to explain recent developments. In this article, we apply the concept to support the hypothesis that the democratic revival after 1990 in the examined Central and Eastern European countries and related set-up of local (self-) government institutions were more influenced by an earlier path taken than by a more recent one. For this purpose, we undertake a content analysis of relevant legal documents and apply an in-depth comparative approach.
\end{abstract}

Keywords: local (self-)government systems, the Czech Republic, Slovakia, Slovenia, path dependence

\section{Introduction}

The countries of Central and Eastern Europe (CEE) have undergone several crucial shifts in the relatively short period since 1989. These states have had to make huge political, economic and administrative changes (Klimovský 2013). Nevertheless, Rupnik (2000) argues that it was naive to expect that the legacy of the communist regimes would disappear quickly from these countries. On the contrary, he stresses that this is a long-term process that can be compared to the fall of the Roman or Ottoman empire. If Rupnik is right - and we agree with him at least in part - then the accession of these states to so-called western structures was only one of the very first steps on a path with an unclear objective.

In the 1990s, most of the CEE countries introduced "new “ democratic systems of local self-government. In some cases, however, this change was arguably 
more of a revival of democratic institutions since the state concerned had previously enjoyed some kind of democratic local self-government system. If this interpretation is correct, then the path dependence concept may help explain some developments since any revival allows us to identify links between the present and past events.

Building on this background, this study aims to show that path dependence played an important role in the reforms leading to the revival of local self-government systems in the examined CEE countries. Furthermore, we argue that the post-1990 democratic revival in these countries and related set-up of local self-government institutions were more influenced by an early path taken than by a more recent one. For this purpose, we undertake a content analysis of relevant legal documents and apply a rigorous comparative approach.

\section{Historical development of local systems of (self-)government}

The former eastern bloc countries found themselves in very different circumstances when they embarked on the transition process. Among other things, these states had different historical and cultural legacies, geographies and economic and social structures. They also devoted different lengths of time to the central planning process and had different experiences of market reforms. Some countries - for example, the Czech Republic, Hungary and Poland -had an industrial economic base or had experimented with economic reforms and could more easily deregulate their economies (UN 2000: 10). In contrast, in other states, the pre-1989 economy depended on the saturation of other socialist bloc markets with „politically ordered“ products. Of all the former Soviet countries, the Baltic states were thought to have the most developed economies. On regaining independence in 1991, their governments undertook comprehensive economic and political reforms (Berengaut - Lopez-Claros 1998: 2). More generally, however, the CEE countries were ill-equipped to pursue change in the early 1990s; they remained encumbered by inadequate public administrative structures inherited from former regimes. Major political and economic structural changes, thus, failed to be accompanied by a steady stream of public administrative reforms (UN 2000: 11).

\section{The Czech Republic}

The beginning of local self-government in the Czech lands can be traced to the revolutionary year of 1848 , which led to the abolition of bonds of servitude and replacement of a patrimonial administration with a state one (ČSÚ 2006: 9). Alongside the „higher" spheres of district and regional municipalities, local municipalities were defined in detail and their powers were classified as innate or delegated (ČSÚ 2006: 11). Innate powers included powers associated with 
elections and self-government bodies' procedures, but their primary focus was economic matters. A new municipal law affected both the operation of municipalities and their structure; in particular, it facilitated and promoted the amalgamation of municipalities based on the limited resources in some areas and the integration of suburbs (Balík 2009: 40; Čopík 2014: 28). Local self-government bodies were established in the form of directly elected municipal committees and the municipal boards that they, in turn, elected. While these boards had decision-making and supervisory powers, they remained supporting and deputy bodies to a burgrave with powers of his own (Balík 2009: 30; Čopík 2014: 29). Municipal committees were elected for three years based on a simple voting majority. Voting was direct but also non-universal and unequal among the public with voters divided into clusters based on their tax payments (Balík 2003: 13); there was an oral ballot (Čopík 2014: 29). Shortly after the establishment of the local self-government system, the former absolutist regime was reinstated and the new system was temporarily restricted under so-called New Year's Eve patents (Čmejrek et al. 2010: 21). On the fall of this „Bach's absolutism, " however, constitutionalism was restored and reinforced, and a second round of municipal elections took place in 1861 (Čmejrek et al. 2010: 21-22). The adoption of a new constitution and municipal legislation between 1861 and 1862 helped establish the local self-government system (Balík 2009, Schelle 2005), however this only covered the area that would eventually be Cisleithania; within the Habsburg monarchy, it included the Czech lands and present-day Slovenia but not Slovakia (the future Transleithania). After the abolition of the regional system in 1860, public administration occurred at the levels of the state, land (země), district and municipality (Čopík 2014: 21) The public administration system at municipal level may be describe as mixed. Municipalities had innate power over economic management, security, local infrastructure, social services for the poor and the performance of most police duties (Balík 2009: 42, Čmejrek et al. 2010: 23-24). At the same time, they were increasingly burdened with delegated power over administrative and financial matters (Balík 2009: 41-42; Čmejrek et al. 2010: 24).

From a local government perspective, the years after Czechoslovakia's foundation in 1918 were marked by continuity. No significant changes to the number of municipalities occurred, and nor was the decentralisation of operations reinforced (Schelle 1991a). Municipal institutions were, however, renamed, with municipal committees coming to be known as „boards“ and municipal boards of directors as „councils“ (Balík 2009: 48-49). The councils strengthened their position as administrative bodies and evolved into decision-making entities; the position of mayors was correspondingly weakened. Municipal elections were based on a proportional representation system with predetermined candidate lists; a relative majority system was used in small municipalities (Balík 2003: 15). The introduction of the proportional system was connected with the most 
significant change of the era, the adoption of universal suffrage including voting rights for women (Balík 2013: 14). Furthermore, since the municipal system included consensus-based and consociational elements, even minority parties had the chance to participate in the executive sphere (Balík 2009: 51). The inter-war period saw changes to the public administration system mainly at a higher level. Counties (in Czech: „župa“) were established as a level of power higher than districts. There were nine counties in Bohemia, five in Moravia and just one in Silesia (Schelle 1991a). Between 1927 and 1928, the politically controversial county system was replaced by a new land system. As a result, the Czech part of Czechoslovakia was divided into two lands: Bohemia and Moravia-Silesia (Čopík 2014, Schelle 1991b). The separate public administration systems used at the district and land levels were also replaced by a mixed system (Čopík 2014: 91). As in the pre-war years, public administration happened at the levels of the state, land, district and municipality.

Local self-government was gradually confined during the Second Republic, and under the subsequent German occupation, it vanished from both the annexed borderland and the Protectorate of Bohemia and Moravia (Balík 2009: 54-55). There was almost no sign of its reestablishment in the post-war years. At first, national committees were formed to serve as municipal institutions, but they were soon subordinated to national committees at a higher level of public administration. Any hopes of reviving local self-government were definitively put aside after the communist coup of 1948 when the dying democratic state was indisputably superseded by a centralist socialist regime. Around this time, the national committee system applied at the municipal and district levels as well as a newly established regional tier. Owing to amalgamations, the number of municipalities declined significantly between the 1960s and the 1980s. While in 1950 there had been 10,877 municipalities in the Czech lands (ČSÚ 2006: 34 ), by 1989, the figure was only 4,120 (Illner 2010: 223). From 1954, members of the general assembly of national committees were directly elected based on a voting majority in each (single mandate) electorate. In practice, however, these elections were merely a formality and deputies with a mandate could still be removed from office (Čmejrek et al. 2010: 35). As in the inter-war period, participating in elections was mandatory.

The years after 1989 saw a resurgence of local self-government. In 1990, new legislation was adopted and the first free municipal elections were held. The centralised municipality system disintegrated and the number of municipalities grew rapidly as even small municipalities strove for autonomy in response to past bad experiences of amalgamation. By 1993, the number of municipalities had approximately doubled (Illner 2010: 223) and the Czech municipal structure had come to rival its French and Slovak counterparts as the most fragmented in Europe. The municipal system bore traces of First Republic legislation. A collective leadership model was used (Heinelt - Hlepas 
2006: 31-32) that included a directly elected board, a council, which served as an executive body, and an indirectly elected mayor, who was head of the municipality. Mayors had no significant executive powers (Jüptner 2008: 23), however in small municipalities especially, their position was very strong (Kopřiva - Čopík - Čmejrek 2017: 499). This was due in part to the their status as the only full-time officials, the weak party system, the consensus-based political culture and their role in presiding over board proceedings. Councillors were elected for a four-year term based on proportional representation with the option of cross voting (Jüptner 2008: 22-23). At first, the state retained separate administrative powers, which were exercised primarily by district authorities. As a result of reforms, however, 73 district offices were abolished in 2003 and state duties were largely delegated to 205 municipalities with expanded powers (Postránecký 2004: 15). A system of mixed public administrative powers was therefore restored, with the municipalities being divided into three categories based on the extent of their delegated state powers. Back in 1989, the eight „communist" regions had been dissolved swiftly, and in 2000, 14 self-governing districts were established under the same name, i.e. as "regions." Their boards were directly elected and the public administration system was again mixed owing to the exercise of delegated powers. As at municipal level, a proportional representation system was implemented, but while independent candidates could be nominated for municipal positions, they could not stand for regional ones.

Turning to current issues, financing is an ongoing problem that affects local autonomy in multi-level governments, or the so-called vertical dimension (Heinelt - Hlepas 2006:21-22). In particular, small municipalities lack the resources to fund their own development and given the asymmetrical municipal structure, they often have diverging interests (Kruntorádová 2013: 64). Still, despite the financial barriers, both the decentralisation process and the restoration of local self-government have been relatively straightforward in the Czech Republic in contrast with the situations in Slovakia and Croatia (Jüptner 2009: 106-108). Except in the case of some specialist offices, public administration takes place at the levels of the state, region and several categories of municipality. Across the executive level of local government (or what Heinelt and Hlepas (2006) call the "horizontal dimension“ (pp. 29-32)), discussions have focused on implementing a new system of direct election of mayors, with both centrist parties and mayors' groups advocating for this change (Jüptner 2017: 212-213).

At the same time, there has been talk of applying the Slovak model, which gives mayors a stronger position (Heinelt - Hlepas 2006: 31-32) including executive power. So far, however, all attempts to implement these direct elections have failed, however, and the traditional system of collective decision-making seems likely to be preserved. 


\section{Slovakia}

At the end of 19th century, the right to self-govern was vested in all Slovak towns and recognised city municipalities. These entities were responsible for issues such as local roads, municipal schools, public security, local taxes and the administration of municipal property. Municipalities fell into three categories: 1 ) towns with their own magistrates, 2) large municipalities and 3) small municipalities. Towns with their own magistrates included all towns established by royalty or the nobility. For administrative purposes, these towns were directly overseen by regional governments but they had their own municipal directorates and their own appointed magistrates who were aldermen, police captains, leading notaries and municipal doctors. Large municipalities did not have their own magistrates but could independently enforce all relevant decisions approved by the central or regional government. The political and administrative leaders of these municipalities were known as mayors. In contrast, small municipalities were not allowed to implement decisions independently and they therefore had to cooperate within notarial districts. These municipalities were also led by mayors andrelevant notaries were elected to their positions for life (Sokolovský 1995a, 1995b).

During World War I, national committees were established to manage the municipalities in what is now Slovak territory (Kováč 1998). This was, however, a slow and uncoordinated process and matters at the local level remained highly messy between 1917 and 1919. Schelle (1991a, 1991b) observes the importance of reforms of the local administration system. The Local Elections Act (No. 75/1919) introduced key principles including universal and equal suffrage and the secret ballot. An amendment to the Municipal Establishment Act (No. 76/1919) changed the institutional structure of local self-government. National committees were dissolved and local councils were established as the main collective decision-making bodies. Their members were elected directly by the residents of the municipality, with the total number of councillors in individual municipalities ranging from nine to 60 . The amendment also established other bodies at the local level, including executive and advisory committees and deputy mayors, who constituted individual bodies. The term of office for all municipal entities, including mayors and deputy mayors, was four years, but mayors were elected indirectly, i.e. by local councils.

A few key centralisation measures were implemented in 1933. The first of these was the extension of municipal councils' term of office from four to six years. The second took the form of a new requirement that the State Office or Interior Ministry confirm successful mayoral candidates. If these authorities did not confirm a candidate and the local council disregarded this situation, the council could be dissolved and the unconfirmed candidate banned from election for the next three years. This growing centralisation of power also led 
councils to shift their focus from self-government to state administrative tasks, especially in the areas of policing, agriculture and social, public health and trade administration (Táborský 1951).

A combination of international and domestic political developments between 1938 and 1939 led to the establishment of the independent Slovak Republic. Although officially an independent country, this republic was in fact a mere satellite state of Germany with a central national clerical government. In this context, the entire self-government system was dissolved (Klimovský 2014), and it was not until after the Slovak national uprising in August 1944 that national committees were re-established. The process lasted several months and after World War II, these committees were in place for all Slovak municipalities (Kováč 1998).

The national committee system was somewhat modified between 1949 and 1950 when the system of bodies was elaborated in more detail. National committees were defined as public authorities responsible for the administration of internal matters, including education, culture, public health, social and financial issues and labour protection. A strict hierarchy system was introduced for public administrations such that national committees for local areas were directly controlled by the central government. There were two kinds of collective bodies in each national committee: a national committee council and specialist committee(s). The national committees also two featured kinds of individual participants: the national committee chair and other civil servants (Schelle 2005).

The year 1954 saw the adoption of more legislation about the national committees responsible for local areas. The National Committees Act (No. 13/1954) largely confirmed rigid existing hierarchies and entitled national committees to authorise their own legal actions. A new National Committees Act (No. $65 / 1960$ ) established the general assembly of national committees as the most important decision-making body, and an executive committee was introduced as the main executive body. Since the national committees were responsible for many state administrative tasks, a decision was made to reduce the overall number of municipalities. This proved unsuccessful, however, and as a result, "nodal" municipalities were introduced into the local government system in 1982. This meant that there were three different categories of national committees operating at the local level: 1) national committees for nodal municipalities; 2) national committees with responsibility for several other kinds of municipalities and 3) national committees with other local concerns. Similarly, three kinds of urban national committees were responsible for towns.

Under the Municipal Establishment Act (No. 369/1990), municipalities regained their self-governing status and their main role became the administration of public affairs not classified as state administration issues. In this way, Slovak municipalities became fully-fledged policy-makers at the local level (Klimovský 
2010: 240) and the national committee system was abolished. Significantly, commentators such as Čapková (2010) and Nižňanský (2005) have characterised the period between 1992 and 1998 as one of disjointed public administrative reforms. These reforms continued with a massive devolution between 2002 and 2004 (Klimovský 2009) and "fiscal decentralisation“ became a catchphrase in the public debate over the next few years (Buček 2006; Čavojec - Sloboda 2005). In response, all major political parties pledged to decentralise power over public funds, and a fiscal decentralisation policy was introduced in 2005 (Kling - Nižňanský 2003). A municipal amalgamation proposal was also announced for 2004-2005, but it was never implemented, and the structure of local government therefore remains very fragmented (Buček - Nemec 2012). Municipalities are entitled to co-operate with one another if this will allow them to perform their tasks better or more efficiently. This also covers potential cross-border partnerships.

The main local (self-)government bodies in Slovakia are mayors (executive entities) and municipal councils (collective decision-making entities). Mayors are directly elected based on a first-past-the-post system, and their term of office is four years, i.e. the same period provided to municipal councils. Mayors are the most influential actors in the local self-government system. Other bodies include executive and advisory committees though some of these only apply to larger municipalities. Municipalities exercise extensive powers regardless of their population or area. The state may also transfer other powers to the local level provided that it allocates the necessary financial resources to the municipality.

\section{Slovenia}

Slovenian territory has changed considerably over the course of modern history. In 1845, the Slovene lands were located between Istria, Carniola, Styria, Croatia, Carinthia and Hungary. Individual lands were divided into administrative provinces and smaller administrative units (districts, municipalities). The leaders of these provinces were strictly bound by the orders of the central administration. Lower-level administrative systems were also developed within the tax system and military service (Grafenauer 2000: 86; Vlaj 2006: 33). Nevertheless, before 1849 , local self-government only existed to a limited extent in Slovenia and the concept only has meaning if it is understood to describe an autonomous medieval city (Grafenauer 2000: 87; Šmidovnik 1995: 146); otherwise it would be more accurate to speak of a deconcentrated system for fulfilling supranational tasks at the lowest possible level. Grafenauer (2000: 87-89) notes that the autonomy of medieval cities diminished over the 18th and 19th centuries but increased under the Habsburg monarchy with its administrative district system (Šmidovnik 1995: 147). In 1914, the area that is now Slovenia was split into eight Austro-Hungarian lands. According to Grafenauer (2000), since 
1850 the municipalities had also been ruled by lands, which set the principles for managing local issues. However, beginning from 1862, in at least two of the larger regions of present-day Slovenia, the municipalities had roughly the same powers as the territories. As such, their responsibilities included managing the local budget, maintaining local roads, ensuring local peace and order and providing social security (Grafenauer 2000: 113).

In the inter-war period, Slovenian territory was subject to three different state entities: the State of Slovenes, Croats and Serbs; the Kingdom of Serbs, Croats and Slovenes; and the Kingdom of Yugoslavia. Moreover, various parts of present-day Slovenia were still ruled by Italy, Austria or Hungary. At the same time, a local self-government system was implemented under which the national government systematically controlled lower levels of government (Grafenauer 2000: 175). Under this system, higher-ranking leaders could block lower level activities, the Ministry of Finance could control local finances and the national assembly could take over local level tasks (Grafenauer 2000: 175). Even so, municipalities' basic powers did not differ significantly from those established 50 years earlier when it came to local finance and local road management or social and general municipal security. As in the past, the centralised control and leadership of municipalities remained basic features of the local (self-)government system. Or, to be more accurate, such centralisation increased since while the lands had controlled the municipalities in the Habsburg period, national level institutions could now interfere in local matter.

After World War II, Slovenia took seven years to normalise its local administration system. Under a 1952 statute, the country was divided into cities (mesto), counties (okraj) and municipalities (občina) (Grafenauer 2000: 285). Celje, Maribor and Ljubljana were each defined as cities. There were also 19 counties and another nine municipalities inside the B-zone in the Trieste area. This brought the national total to 386 municipalities including 44 city municipalities. In 1955, many of these municipalities were changed into "communes," a concept taken from the Paris commune model, which held that these were the cells of a future socialist society (Grafenauer 2000: 300-301; Vlaj 2006: 36-42). The total number of municipalities, thus, dropped from 386 to 130 . The commune idea was gradually abandoned, however the number of municipalities continued to fall steadily; in 1960, there were 83 municipalities and in 1964, there were just 62 (Grafenauer 2000: 312; Šmidovnik 1995: 153). The constitutional reforms of 1974 redefined the municipalities and gave them broader powers. Among other things, they were made responsible for ensuring good living conditions, directing social development, supporting the interests of residents, meeting local population needs and performing various government operations and other societal roles (Grafenauer 2000: 325). Based on the different organisation system in place from 1974 to 1990, the number of municipalities rose to 66, but it was reduced again to 62 before 1994 (Grafenauer 2000: 34-347; Šmidovnik 1995: 153-155). 
In 1991, the independent Republic of Slovenia adopted a new constitution that restored local government to its classic role. Municipalities were seen as the foundation of the system and the place for dealing with public issues of local importance (Vlaj 2006: 41). The constitution also identified local self-government as a significant part of the Slovenian political system.

In terms of sheer numbers, the recent history of the Slovenian municipalities highlights a move to decentralise local self-government, with responsibilities being assigned to the smallest units possible. Slovenia has undertaken five reforms of local government divisions, which have increased the number of municipalities by more than 340\% - from 62 before 1994 to 212 in 2014 .

Under the country's Local Self-government Act, municipalities are afforded various powers so they can provide relevant services to their residents. Nevertheless, the devolution has been limited in comparison with the situation in some other CEE countries, and Slovenia is significantly less decentralised than, for instance, Slovakia. In addition, the state may delegate some of its responsibilities to the local level. The tasks in question may be assigned to a specific type of municipality, to all municipalities or to one municipality in particular. In all such cases, however, the state must ensure the necessary funding.

Mayors (executive entities) and municipal councils (collective decision-making entities) are the main municipal institutions in Slovenia. Mayors are elected every four years based on a voting majority in a two-round process. Municipal councils are elected every four years as well. There are, however, different election systems depending on the population size: a simple majority applies in smaller municipalities while proportional representation is used in larger municipalities.

\section{Methodology}

Since our analysis addresses the potential impact of various historical developments on current social, economic and political phenomena, the path dependence concept is highly relevant. This concept was initially very popular among economists and economic geographers (see, e.g., Arthur 1994; BoschmaMartin 2010; Garrouste - Ioannides 2001) but in recent decades, it has also been used by lawyers, sociologists, historians and political scientists (see, e.g., Crouch - Farrell 2004; Liebowitz - Margolis 1995; Pierson 2000, 2004). Anyone applying the concept in the context of social (including political) research must, however, be mindful of its limitations (David 2001). In this regard, Kay (2005) points out three general limits of the framework: 1) it fashionably reflects the intuition that „history matters" without giving any clear or convincing account of decision-making over time; 2 ) it explains only stability and not change and 3 ) its normative implications are confusing and have mostly been left unexplored. Given the difficulties that also surround the operationalisation and empirical 
testing of the concept, social scientists should be highly cautious when formulating conclusions.

In defining path dependence and the forms it may take, we draw on the framework provided by Page (2006):

A process is path-dependent if the outcome in any period depends on history and can depend on its order.

A process is independent if the outcome in any period does not depend upon past outcomes or upon the time period.

$[\ldots]$

A process is initial outcome-dependent if all subsequent outcomes depend only on the first outcome.

A process is early path-dependent if the outcome in any subsequent period depends only upon the history up to some period T.

A process is recent path-dependent if the outcome in any subsequent period depends only upon the outcomes and opportunities in the recent past. $[\ldots]$

A process is outcome-dependent if the outcome in a period depends on past outcomes or upon the time period.

A process is state-dependent, if the outcome in any period depends only upon the state of the process at that time.

(pp. 92-105)

Our analysis compares three CEE countries, i.e. the Czech Republic, Slovakia and Slovenia. This selection is justified based on the historical similarities among these countries, i.e. each one has experienced the Habsburg monarchy, inter-war democracy, a socialist period and subsequent transition. Based on these historical divisions - an initial period, the distant history, the recent past and the present - we developed a comparative assessment tool that focused on certain basic criteria. The goal was to identify and explore historical similarities and differences in the local self-government systems in these countries.

To this end, we selected three main groups of characteristics that were then compared across the three countries in the stated eras. The first group included traits related to "centralisation" (the extent of local subordination to the national level); "layers of sub-national government" (the distance between the national level and the lowest rung of local authority); „state administration tasks" (the number of tasks delegated by national administrators to their local counterparts); „scope of regulation“ (the extent of national interference in local issues) and „concentration“ (trends, i.e. increases or decreases, in the number of municipalities). The second group focused on „fiscal autonomy vis-à-vis the state" (the local level's capacity to independently manage financial issues within its budget) and „possibility of introducing own local taxes/fees or modifying 
their rates" (municipalities' autonomy over their own revenue in addition to their budget). The third group considered the factors „main decision-making body,“ „main executive body“ and „power relations between the main decision-making body and the main executive body" (potential for the subordination of either body in different decision-making practices) (Table 1).

Table 1: Comparative indicators

\begin{tabular}{|c|c|c|c|c|c|}
\hline & 1 & 2 & 3 & 4 & 5 \\
\hline Centralization & Minimal state & $\begin{array}{l}\text { Decentralized } \\
\text { state }\end{array}$ & $\begin{array}{c}\text { Government } \\
\text { dominated local } \\
\text { government }\end{array}$ & $\begin{array}{l}\text { Centralized } \\
\text { state }\end{array}$ & $\begin{array}{l}\text { Absence of } \\
\text { local level }\end{array}$ \\
\hline $\begin{array}{l}\text { Concentration } \\
\text { trend }\end{array}$ & $\begin{array}{l}\text { Deep decrease } \\
\text { in number of } \\
\text { municipalities } \\
\text { (more than } \\
\text { 20\%) }\end{array}$ & $\begin{array}{c}\text { Moderate } \\
\text { decrease in } \\
\text { number of } \\
\text { municipalities } \\
\text { (up to 20\%) }\end{array}$ & Stable & $\begin{array}{c}\text { Moderate } \\
\text { increase in } \\
\text { number of } \\
\text { municipalities } \\
\text { (up to 20\%) }\end{array}$ & $\begin{array}{l}\text { High increase } \\
\text { in number of } \\
\text { municipalities } \\
\text { (more than } \\
20 \% \text { ) }\end{array}$ \\
\hline $\begin{array}{l}\text { Performing } \\
\text { state } \\
\text { administration }\end{array}$ & $\begin{array}{l}\text { No delegated } \\
\text { tasks }\end{array}$ & $\begin{array}{l}\text { Few delegated } \\
\text { tasks }\end{array}$ & \begin{tabular}{|c|} 
Majority or/ \\
major state \\
tasks delegated \\
\end{tabular} & Minimal state & / \\
\hline $\begin{array}{l}\text { Degree of } \\
\text { regulation of } \\
\text { competences }\end{array}$ & $\begin{array}{l}\text { No influence on } \\
\text { public policy }\end{array}$ & $\begin{array}{c}\text { Possibility to } \\
\text { propose and } \\
\text { partly influence } \\
\text { public policy }\end{array}$ & $\begin{array}{c}\text { Possibility of } \\
\text { influence on } \\
\text { public policy in } \\
\text { less important } \\
\text { matters }\end{array}$ & $\begin{array}{l}\text { Co-deciding on } \\
\text { all matters of } \\
\text { public policy }\end{array}$ & $\begin{array}{c}\text { Municipalities } \\
\text { are absolutely } \\
\text { autonomous } \\
\text { in public policy } \\
\text { making }\end{array}$ \\
\hline $\begin{array}{l}\text { Possibility to } \\
\text { introduce own } \\
\text { local taxes or } \\
\text { to modify their } \\
\text { rates }\end{array}$ & $\begin{array}{l}\text { No possibility } \\
\text { to influence } \\
\text { own tax } \\
\text { revenues }\end{array}$ & $\begin{array}{c}\text { Possibility to } \\
\text { introduce some } \\
\text { local taxes }\end{array}$ & \begin{tabular}{|} 
Possibility to \\
modify tax \\
rates within the \\
limit
\end{tabular} & \begin{tabular}{|c|} 
Municipalities \\
can introduce \\
some regulated \\
taxes for and \\
influence levels \\
of state taxes \\
for their budget \\
\end{tabular} & $\begin{array}{c}\text { Municipalities } \\
\text { can } \\
\text { autonomously } \\
\text { define new } \\
\text { taxes }\end{array}$ \\
\hline $\begin{array}{l}\text { Possibility to } \\
\text { introduce own } \\
\text { local fees or to } \\
\text { modify their } \\
\text { rates }\end{array}$ & $\begin{array}{l}\text { No possibility } \\
\text { to influence } \\
\text { own fee } \\
\text { revenues }\end{array}$ & $\begin{array}{l}\text { Possibility to } \\
\text { introduce some } \\
\text { local fees }\end{array}$ & $\begin{array}{c}\text { Possibility to } \\
\text { modify tax } \\
\text { rates within the } \\
\text { limit }\end{array}$ & $\begin{array}{c}\text { Municipalities } \\
\text { can introduce } \\
\text { some regulated } \\
\text { fees for }\end{array}$ & $\begin{array}{l}\text { Municipalities } \\
\text { can } \\
\text { autonomously } \\
\text { define new fees }\end{array}$ \\
\hline $\begin{array}{l}\text { Main decision } \\
\text { making body }\end{array}$ & Mayor & $\begin{array}{c}\text { Municipal } \\
\text { council }\end{array}$ & $\begin{array}{c}\text { Supervisory } \\
\text { board }\end{array}$ & $\begin{array}{c}\text { Executive } \\
\text { committee }\end{array}$ & / \\
\hline $\begin{array}{l}\text { Main executive } \\
\text { body }\end{array}$ & Mayor & $\begin{array}{c}\text { Municipal } \\
\text { council }\end{array}$ & $\begin{array}{c}\text { Supervisory } \\
\text { board }\end{array}$ & $\begin{array}{c}\text { Executive } \\
\text { committee }\end{array}$ & / \\
\hline $\begin{array}{l}\text { Power relation } \\
\text { between the } \\
\text { main decision } \\
\text { making body } \\
\text { and main } \\
\text { executive body }\end{array}$ & $\begin{array}{c}\text { Municipal } \\
\text { council-centric }\end{array}$ & $\begin{array}{c}\text { Mayor-centric } \\
\text { or } \\
\text { Executive } \\
\text { committee- } \\
\text { centric }\end{array}$ & $\begin{array}{l}\text { Supervisory } \\
\text { board-centric }\end{array}$ & / & / \\
\hline $\begin{array}{l}\text { Layers of } \\
\text { sub-national } \\
\text { government }\end{array}$ & $\begin{array}{l}\text { No local self- } \\
\text { government }\end{array}$ & Municipalities & $\begin{array}{c}\text { Municipalities + } \\
\text { regions }\end{array}$ & $\begin{array}{c}\text { Municipalities } \\
+ \text { regions } 1+ \\
\text { regions } 2\end{array}$ & / \\
\hline
\end{tabular}

Source: authors 
Our assumptions were as follows:

1) Signs of path dependence can be detected in the development of local self-government systems in the selected countries.

2) While the development of these systems in the selected countries was outcome-dependent after 1990, it was fairly state-dependent in the socialist period.

3) The post-1990 development of local self-government systems in these countries was early path-dependent. This dependence is mainly tied to the inter-war period.

In order to test these assumptions, we undertook a content analysis of relevant legal documents (statutes dating back to approximately the mid-1850s) and applied a rigorous comparative approach. Our conclusions are supported by qualitative data and the arguments of relevant scholars, including recent work by Bakoš, Soukopová and Selešovský (2015). Our analysis considers neither the performance of local self-government nor issues in local politics. In other words, our goal is not to compare the efficiency or effectiveness of these systems, and we therefore do not consider the issue of the replacement of local political elites, for example. Our research focuses only on the set-up of institutions and relevant legal provisions. As such, we are aware that our conclusions have some limitations, and we accept that different interpretations of these developments might also apply.

\section{Comparative analysis of historical developments}

Despite the general historical similarities among the Czech Republic, Slovakia and Slovenia, a comparison of developments in these countries and their current local self-government systems reveals significant differences (Tables 2-8). 
Table 2: A comparison of features of (self-)government systems during the Habsburg monarchy

\begin{tabular}{|c|c|c|c|}
\hline \multirow{2}{*}{$\begin{array}{l}\text { Period } \\
\text { Country }\end{array}$} & \multicolumn{3}{|c|}{ Period of Habsburg monarchy } \\
\hline & Slovenia & Slovakia & Czech Republic \\
\hline Centralization & $\begin{array}{l}\text { Government } \\
\text { dominated local } \\
\text { government }\end{array}$ & $\begin{array}{l}\text { Government } \\
\text { dominated local } \\
\text { government }\end{array}$ & $\begin{array}{l}\text { Government } \\
\text { dominated local } \\
\text { government }\end{array}$ \\
\hline Concentration trend & $\begin{array}{l}\text { Deep decrease } \\
\text { in number of } \\
\text { municipalities }\end{array}$ & $\begin{array}{l}\text { Moderate increase } \\
\text { in number of } \\
\text { municipalities }\end{array}$ & $\begin{array}{l}\text { Moderate increase } \\
\text { in number of } \\
\text { municipalities }\end{array}$ \\
\hline $\begin{array}{l}\text { Performing state } \\
\text { administration }\end{array}$ & No delegated tasks & Few delegated tasks & $\begin{array}{l}\text { Majority or/major } \\
\text { state tasks delegated }\end{array}$ \\
\hline $\begin{array}{l}\text { Degree of regulation of } \\
\text { competences }\end{array}$ & $\begin{array}{l}\text { No influence on public } \\
\text { policy }\end{array}$ & $\begin{array}{l}\text { Co-deciding on all } \\
\text { matters of public } \\
\text { policy }\end{array}$ & $\begin{array}{l}\text { Co-deciding on all } \\
\text { matters of public } \\
\text { policy }\end{array}$ \\
\hline $\begin{array}{l}\text { Possibility to introduce } \\
\text { own local taxes or to } \\
\text { modify their rates }\end{array}$ & $\begin{array}{l}\text { No possibility to } \\
\text { influence own tax } \\
\text { revenues }\end{array}$ & $\begin{array}{l}\text { Possibility to } \\
\text { introduce some local } \\
\text { taxes }\end{array}$ & $\begin{array}{c}\text { Possibility to } \\
\text { introduce some local } \\
\text { taxes }\end{array}$ \\
\hline $\begin{array}{l}\text { Possibility to introduce } \\
\text { own local fees or to modify } \\
\text { their rates }\end{array}$ & $\begin{array}{l}\text { No possibility to } \\
\text { influence own fee } \\
\text { revenues }\end{array}$ & $\begin{array}{l}\text { Possibility to } \\
\text { introduce some local } \\
\text { fees }\end{array}$ & $\begin{array}{l}\text { Possibility to } \\
\text { introduce some local } \\
\text { taxes }\end{array}$ \\
\hline Main decision making body & Municipal council & Municipal council & Municipal council \\
\hline Main executive body & Mayor & Magistrate & Mayor \\
\hline $\begin{array}{l}\text { Power relation between } \\
\text { the main decision making } \\
\text { body and main executive } \\
\text { body }\end{array}$ & $\begin{array}{l}\text { Municipal council- } \\
\text { centric }\end{array}$ & $\begin{array}{l}\text { Magistrate-centric } \\
\text { Executive committee- } \\
\text { centric }\end{array}$ & $\begin{array}{l}\text { Municipal council- } \\
\text { centric }\end{array}$ \\
\hline $\begin{array}{l}\text { Layers of sub-national } \\
\text { government }\end{array}$ & $\begin{array}{l}\text { Municipalities + } \\
\text { regions } 1+\text { regions } 2\end{array}$ & $\begin{array}{l}\text { Municipalities + } \\
\text { regions } 1+\text { regions } 2\end{array}$ & $\begin{array}{c}\text { Municipalities + } \\
\text { regions 1 + regions } 2\end{array}$ \\
\hline
\end{tabular}

Source: authors (based on relevant legal provisions) 


\section{Table 3: A comparison of features of local (self-)government systems in the inter-war period}

\begin{tabular}{|c|c|c|c|}
\hline \multirow{2}{*}{$\begin{array}{l}\text { Period } \\
\text { Country }\end{array}$} & \multicolumn{3}{|c|}{ Inter-war period } \\
\hline & Slovenia & Slovakia & Czech Republic \\
\hline Centralization & Centralized state & $\begin{array}{l}\text { First decade } \\
\text { government } \\
\text { dominated local } \\
\text { government, later } \\
\text { centralized state }\end{array}$ & $\begin{array}{l}\text { First decade } \\
\text { government } \\
\text { dominated local } \\
\text { government }\end{array}$ \\
\hline Concentration trend & $\begin{array}{l}\text { Moderate decrease } \\
\text { in number of } \\
\text { municipalities }\end{array}$ & $\begin{array}{l}\text { Moderate increase } \\
\text { in number of } \\
\text { municipalities }\end{array}$ & $\begin{array}{l}\text { Moderate increase } \\
\text { in number of } \\
\text { municipalities }\end{array}$ \\
\hline $\begin{array}{l}\text { Performing state } \\
\text { administration }\end{array}$ & Few delegated tasks & $\begin{array}{c}\text { Majority or/major } \\
\text { state tasks delegated }\end{array}$ & $\begin{array}{c}\text { Majority or/major } \\
\text { state tasks delegated }\end{array}$ \\
\hline $\begin{array}{l}\text { Degree of regulation of } \\
\text { competences }\end{array}$ & $\begin{array}{l}\text { Possibility to propose } \\
\text { and partly influence } \\
\text { public policy }\end{array}$ & $\begin{array}{c}\text { Possibility of influence } \\
\text { on public policy in less } \\
\text { important matters }\end{array}$ & $\begin{array}{c}\text { Possibility of influence } \\
\text { on public policy in less } \\
\text { important matters }\end{array}$ \\
\hline $\begin{array}{l}\text { Possibility to introduce } \\
\text { own local taxes or to } \\
\text { modify their rates }\end{array}$ & $\begin{array}{l}\text { Possibility to } \\
\text { introduce some local } \\
\text { taxes }\end{array}$ & $\begin{array}{l}\text { Municipalities can } \\
\text { introduce some } \\
\text { regulated taxes for } \\
\text { and slightly influence } \\
\text { levels of state taxes } \\
\text { for their budget }\end{array}$ & $\begin{array}{l}\text { Municipalities can } \\
\text { introduce some } \\
\text { regulated taxes for } \\
\text { and slightly influence } \\
\text { levels of state taxes } \\
\text { for their budget }\end{array}$ \\
\hline $\begin{array}{l}\text { Possibility to introduce } \\
\text { own local fees or to modify } \\
\text { their rates }\end{array}$ & $\begin{array}{c}\text { Possibility to } \\
\text { introduce some local } \\
\text { fees } \\
\end{array}$ & $\begin{array}{l}\text { Possibility to } \\
\text { introduce some local } \\
\text { fees }\end{array}$ & $\begin{array}{c}\text { Possibility to } \\
\text { introduce some local } \\
\text { fees }\end{array}$ \\
\hline Main decision making body & Municipal council & Municipal council & Municipal council \\
\hline Main executive body & Mayor & Mayor & Executive committee \\
\hline $\begin{array}{l}\text { Power relation between } \\
\text { the main decision making } \\
\text { body and main executive } \\
\text { body }\end{array}$ & $\begin{array}{l}\text { Municipal council- } \\
\text { centric }\end{array}$ & $\begin{array}{l}\text { Municipal/local } \\
\text { council-centric }\end{array}$ & $\begin{array}{l}\text { Executive committee- } \\
\text { centric }\end{array}$ \\
\hline $\begin{array}{l}\text { Layers of sub-national } \\
\text { government }\end{array}$ & $\begin{array}{c}\text { Municipalities + } \\
\text { regions } 1+\text { regions } 2\end{array}$ & $\begin{array}{c}\text { Municipalities + } \\
\text { regions } 1+\text { regions } 2 \\
\text { (later without regions } \\
\text { 2) }\end{array}$ & $\begin{array}{c}\text { Municipalities + } \\
\text { regions } 1+\text { regions } 2\end{array}$ \\
\hline
\end{tabular}

Source: authors (based on relevant legal provisions) 
Table 4: A comparison of features of local (self-)government systems in the socialist period

\begin{tabular}{|c|c|c|c|}
\hline \multirow{2}{*}{$\begin{array}{l}\text { Period } \\
\text { Country }\end{array}$} & \multicolumn{3}{|c|}{ Period of socialism } \\
\hline & Slovenia & Slovakia & Czech Republic \\
\hline Centralization & $\begin{array}{l}\text { Government } \\
\text { dominated local } \\
\text { government }\end{array}$ & Centralized state & Centralized state \\
\hline Concentration trend & Stable & $\begin{array}{l}\text { Deep decrease } \\
\text { in number of } \\
\text { municipalities }\end{array}$ & $\begin{array}{l}\text { Deep decrease } \\
\text { in number of } \\
\text { municipalities }\end{array}$ \\
\hline $\begin{array}{l}\text { Performing state } \\
\text { administration }\end{array}$ & $\begin{array}{l}\text { Majority or/major } \\
\text { state tasks delegated }\end{array}$ & $\begin{array}{l}\text { Majority or/major } \\
\text { state tasks delegated }\end{array}$ & $\begin{array}{c}\text { Majority or/major } \\
\text { state tasks delegated }\end{array}$ \\
\hline $\begin{array}{l}\text { Degree of regulation of } \\
\text { competences }\end{array}$ & $\begin{array}{l}\text { Possibility of influence } \\
\text { on public policy in less } \\
\text { important matters }\end{array}$ & $\begin{array}{c}\text { Possibility of influence } \\
\text { on public policy in less } \\
\text { important matters }\end{array}$ & $\begin{array}{c}\text { Possibility of influence } \\
\text { on public policy in less } \\
\text { important matters }\end{array}$ \\
\hline $\begin{array}{l}\text { Possibility to introduce } \\
\text { own local taxes or to } \\
\text { modify their rates }\end{array}$ & $\begin{array}{l}\text { Possibility to modify } \\
\text { tax rates within the } \\
\text { limit }\end{array}$ & $\begin{array}{l}\text { No possibility to } \\
\text { influence own tax } \\
\text { revenues }\end{array}$ & $\begin{array}{l}\text { No possibility to } \\
\text { influence own tax } \\
\text { revenues }\end{array}$ \\
\hline $\begin{array}{l}\text { Possibility to introduce } \\
\text { own local fees or to modify } \\
\text { their rates }\end{array}$ & $\begin{array}{l}\text { Possibility to modify } \\
\text { fee rates within the } \\
\text { limit }\end{array}$ & $\begin{array}{l}\text { No possibility to } \\
\text { influence own fee } \\
\text { revenues }\end{array}$ & $\begin{array}{l}\text { No possibility to } \\
\text { influence own fee } \\
\text { revenues }\end{array}$ \\
\hline Main decision making body & Municipal council & $\begin{array}{l}\text { Local national } \\
\text { committee }\end{array}$ & $\begin{array}{l}\text { Local national } \\
\text { committee }\end{array}$ \\
\hline Main executive body & Mayor & $\begin{array}{l}\text { Chair of the local } \\
\text { national committee }\end{array}$ & $\begin{array}{l}\text { Chair of the local } \\
\text { national committee }\end{array}$ \\
\hline $\begin{array}{l}\text { Power relation between } \\
\text { the main decision making } \\
\text { body and main executive } \\
\text { body }\end{array}$ & $\begin{array}{l}\text { Municipal council- } \\
\text { centric }\end{array}$ & $\begin{array}{l}\text { Mayor-centric } \\
\text { Executive committee- } \\
\text { centric }\end{array}$ & $\begin{array}{l}\text { Mayor-centric } \\
\text { Executive committee- } \\
\text { centric }\end{array}$ \\
\hline $\begin{array}{l}\text { Layers of sub-national } \\
\text { government }\end{array}$ & $\begin{array}{l}\text { Municipalities + } \\
\text { regions }\end{array}$ & $\begin{array}{l}\text { No self-government, } \\
\text { only state } \\
\text { administration: } \\
\text { municipalities + } \\
\text { regions } 1+\text { regions } 2\end{array}$ & $\begin{array}{l}\text { No self-government, } \\
\text { only state } \\
\text { administration: } \\
\text { municipalities + } \\
\text { regions } 1+\text { regions } 2\end{array}$ \\
\hline
\end{tabular}

Source: authors (based on relevant legal provisions) 


\section{Table 5: A comparison of features of local (self-)government systems in the post-1989 era}

\begin{tabular}{|c|c|c|c|}
\hline Period & & Period after 1989 & \\
\hline Country & Slovenia & Slovakia & Czech Republic \\
\hline Centralization & Centralized state & Decentralized state & Decentralized state \\
\hline Concentration trend & $\begin{array}{l}\text { High increase } \\
\text { in number of } \\
\text { municipalities }\end{array}$ & $\begin{array}{l}\text { Moderate increase } \\
\text { in number of } \\
\text { municipalities }\end{array}$ & $\begin{array}{l}\text { High increase } \\
\text { in number of } \\
\text { municipalities }\end{array}$ \\
\hline $\begin{array}{l}\text { Performing state } \\
\text { administration }\end{array}$ & Few delegated tasks & $\begin{array}{c}\text { First decade majority } \\
\text { or/major state tasks } \\
\text { delegated, later a shift } \\
\text { to almost minimal } \\
\text { state }\end{array}$ & Few delegated tasks \\
\hline $\begin{array}{l}\text { Degree of regulation of } \\
\text { competences }\end{array}$ & $\begin{array}{l}\text { Co-deciding on all } \\
\text { matters of public } \\
\text { policy }\end{array}$ & $\begin{array}{l}\text { Municipalities are } \\
\text { autonomous in public } \\
\text { policy making }\end{array}$ & $\begin{array}{c}\text { Co-deciding in } \\
\text { some matters of } \\
\text { public policy and } \\
\text { autonomous in other } \\
\text { matters }\end{array}$ \\
\hline $\begin{array}{l}\text { Possibility to introduce } \\
\text { own local taxes or to } \\
\text { modify their rates }\end{array}$ & $\begin{array}{l}\text { Municipalities can } \\
\text { introduce some } \\
\text { regulated taxes for } \\
\text { and influence levels } \\
\text { of state taxes for their } \\
\text { budget }\end{array}$ & $\begin{array}{l}\text { Municipalities can } \\
\text { introduce some } \\
\text { regulated taxes for } \\
\text { and influence levels } \\
\text { of state taxes for their } \\
\text { budget }\end{array}$ & $\begin{array}{l}\text { Municipalities can } \\
\text { introduce some } \\
\text { regulated taxes for } \\
\text { and influence levels } \\
\text { of state taxes for their } \\
\text { budget }\end{array}$ \\
\hline $\begin{array}{l}\text { Possibility to introduce } \\
\text { own local fees or to modify } \\
\text { their rates }\end{array}$ & $\begin{array}{l}\text { Possibility to } \\
\text { introduce some local } \\
\text { fees }\end{array}$ & $\begin{array}{l}\text { Possibility to modify } \\
\text { fee rates within the } \\
\text { limit }\end{array}$ & $\begin{array}{l}\text { Possibility to modify } \\
\text { fee rates within the } \\
\text { limit }\end{array}$ \\
\hline Main decision making body & Municipal council & Municipal council & Municipal council \\
\hline Main executive body & Mayor & Mayor & Executive committee \\
\hline $\begin{array}{l}\text { Power relation between } \\
\text { the main decision making } \\
\text { body and main executive } \\
\text { body }\end{array}$ & $\begin{array}{l}\text { Municipal council- } \\
\text { centric }\end{array}$ & Mayor-centric & $\begin{array}{l}\text { Mayor-centric / } \\
\text { executive committee- } \\
\text { centric in bigger } \\
\text { municipalities }\end{array}$ \\
\hline $\begin{array}{l}\text { Layers of sub-national } \\
\text { government }\end{array}$ & Municipalities & $\begin{array}{c}\text { In the first decade } \\
\text { just municipalities, } \\
\text { later municipalities + } \\
\text { regions }\end{array}$ & $\begin{array}{c}\text { In the first decade } \\
\text { just municipalities, } \\
\text { later municipalities + } \\
\text { regions }\end{array}$ \\
\hline
\end{tabular}

Source: authors (based on relevant legal provisions) 
Table 6: Historical development of the local (self-)government system in Slovenia

\begin{tabular}{|c|c|c|c|c|}
\hline & $\begin{array}{l}\text { Habsburg } \\
\text { monarchy }\end{array}$ & $\begin{array}{c}\text { Inter-war } \\
\text { period }\end{array}$ & $\begin{array}{l}\text { Period of } \\
\text { socialism }\end{array}$ & $\begin{array}{c}\text { Period } \\
\text { after } 1989 \\
\end{array}$ \\
\hline Centralization & $\begin{array}{c}\text { Relatively decentral- } \\
\text { ized }\end{array}$ & Centralized & $\begin{array}{c}\text { Relatively decentral- } \\
\text { ized }\end{array}$ & Centralized \\
\hline $\begin{array}{l}\text { Layers of } \\
\text { sub-national } \\
\text { government }\end{array}$ & $3-4$ & $3-4$ & $2-3$ & 1 \\
\hline $\begin{array}{l}\text { Performing state } \\
\text { administration }\end{array}$ & Medium & Medium & Medium/high & Low \\
\hline $\begin{array}{l}\text { Fiscal autonomy in } \\
\text { relation to the state }\end{array}$ & None & None & None & None \\
\hline $\begin{array}{l}\text { Possibility to } \\
\text { introduce own local } \\
\text { taxes or to modify } \\
\text { their rates }\end{array}$ & None & None & None & None \\
\hline Concentration trend & $\begin{array}{l}\text { Increasing number } \\
\text { of municipalities }\end{array}$ & $\begin{array}{c}\text { Stable number of } \\
\text { municipalities }\end{array}$ & $\begin{array}{l}\text { Decreasing number } \\
\text { of municipalities }\end{array}$ & $\begin{array}{l}\text { Increasing number } \\
\text { of municipalities }\end{array}$ \\
\hline Major competences & $\begin{array}{l}\text { Local infrastructure, } \\
\text { Local safety and } \\
\text { social security, } \\
\text { Local financial } \\
\text { management }\end{array}$ & $\begin{array}{c}\text { Local infrastructure, } \\
\text { Local safety and } \\
\text { social security, } \\
\text { Local financial } \\
\text { management }\end{array}$ & $\begin{array}{c}\text { Common life mat- } \\
\text { ters, } \\
\text { Directing of social } \\
\text { development, } \\
\text { Enabling inhabit- } \\
\text { ants to fulfil their } \\
\text { interests, } \\
\text { Accomplishing of } \\
\text { common needs of } \\
\text { population in the } \\
\text { area, } \\
\text { Carrying out of dif- } \\
\text { ferent functions of } \\
\text { government, } \\
\text { Performing other } \\
\text { societal roles }\end{array}$ & $\begin{array}{l}\text { Local infrastructure, } \\
\text { Local safety and } \\
\text { social security, } \\
\text { Local financial } \\
\text { management, } \\
\text { Local development, } \\
\text { Performing other } \\
\text { societal roles }\end{array}$ \\
\hline $\begin{array}{l}\text { Degree of } \\
\text { regulation of } \\
\text { competences }\end{array}$ & Low & Low & Medium & High \\
\hline $\begin{array}{l}\text { Main decision } \\
\text { making body }\end{array}$ & Municipal council & Municipal council & $\begin{array}{c}\text { Community com- } \\
\text { mittee }\end{array}$ & Municipal council \\
\hline Main executive body & Mayor & Mayor & Mayor & Mayor \\
\hline $\begin{array}{l}\text { Power relation } \\
\text { between the main } \\
\text { decision making } \\
\text { body and main } \\
\text { executive body }\end{array}$ & $\begin{array}{l}\text { Domination of } \\
\text { executive body }\end{array}$ & $\begin{array}{l}\text { Domination of } \\
\text { executive body }\end{array}$ & $\begin{array}{l}\text { Relative equality } \\
\text { with moderately } \\
\text { stronger position of } \\
\text { the chair }\end{array}$ & $\begin{array}{l}\text { Depending on local } \\
\text { politics (party bal- } \\
\text { ance between mu- } \\
\text { nicipal council and } \\
\text { mayor) }\end{array}$ \\
\hline
\end{tabular}

Source: authors (based on relevant legal provisions) 
Table 7: Historical development of the local (self-)government system in Slovakia

\begin{tabular}{|c|c|c|c|c|}
\hline & $\begin{array}{l}\text { Habsburg } \\
\text { monarchy }\end{array}$ & $\begin{array}{c}\text { Inter-war } \\
\text { period }\end{array}$ & $\begin{array}{l}\text { Period of } \\
\text { socialism }\end{array}$ & $\begin{array}{c}\text { Period } \\
\text { after } 1989\end{array}$ \\
\hline Centralization & $\begin{array}{l}\text { Relatively decentral- } \\
\text { ized }\end{array}$ & $\begin{array}{c}\text { First decade decen- } \\
\text { tralized, later rather } \\
\text { centralized and } \\
\text { during WWII strictly } \\
\text { centralized }\end{array}$ & Centralized & $\begin{array}{l}\text { First decade rather } \\
\text { decentralized and } \\
\text { later highly decen- } \\
\text { tralized }\end{array}$ \\
\hline $\begin{array}{l}\text { Layers of sub- } \\
\text { national government }\end{array}$ & 3 & \begin{tabular}{|c|} 
later 2 with utiliza- \\
tion of unified model \\
(authorities were \\
responsible for both \\
self-government and \\
state administration)
\end{tabular} & $\begin{array}{c}3 \text { with existence of } \\
\text { no self-government } \\
\text { in fact }\end{array}$ & $\begin{array}{l}2 \text { with utilization of } \\
\text { dual model (division } \\
\text { between self-gov- } \\
\text { ernment and state } \\
\text { administration) }\end{array}$ \\
\hline $\begin{array}{l}\text { Performing state } \\
\text { administration }\end{array}$ & Medium & High & Total & Medium \\
\hline $\begin{array}{l}\text { Fiscal autonomy in } \\
\text { relation to the state }\end{array}$ & Low & Low & None & $\begin{array}{l}\text { Low in the first } \\
\text { decade and later } \\
\text { medium }\end{array}$ \\
\hline $\begin{array}{l}\text { Possibility to } \\
\text { introduce own local } \\
\text { taxes or to modify } \\
\text { their rates }\end{array}$ & Low & Low & None & $\begin{array}{l}\text { Low in the first dec- } \\
\text { ade and later high }\end{array}$ \\
\hline Concentration trend & $\begin{array}{l}\text { Increasing number } \\
\text { of municipalities }\end{array}$ & $\begin{array}{l}\text { Increasing number } \\
\text { of municipalities }\end{array}$ & $\begin{array}{l}\text { Obligatory (coordi- } \\
\text { nated by the state) } \\
\text { decreasing of num- } \\
\text { ber of municipalities }\end{array}$ & $\begin{array}{c}\text { Increasing number } \\
\text { of municipalities in } \\
\text { the early 1990s and } \\
\text { later stabile number } \\
\text { of them }\end{array}$ \\
\hline Major competences & $\begin{array}{l}\text { Local infrastructure, } \\
\text { local safety and } \\
\text { social security, public } \\
\text { health and local } \\
\text { education, } \\
\text { local financial man- } \\
\text { agement }\end{array}$ & $\begin{array}{c}\text { Local infrastructure, } \\
\text { local safety and } \\
\text { social security, public } \\
\text { health, local educa- } \\
\text { tion } \\
\text { local financial man- } \\
\text { agement }\end{array}$ & $\begin{array}{c}\text { All public issues that } \\
\text { were not recognized } \\
\text { as the issues that } \\
\text { should be managed } \\
\text { / administered by } \\
\text { some higher author- } \\
\text { ity }\end{array}$ & $\begin{array}{c}\text { Local infrastructure } \\
\text { and transport, local } \\
\text { safety and social se- } \\
\text { curity, public health } \\
\text { and local educa- } \\
\text { tion, protection of } \\
\text { environment, local } \\
\text { financial manage- } \\
\text { ment }\end{array}$ \\
\hline $\begin{array}{l}\text { Degree of regulation } \\
\text { of competences }\end{array}$ & Low & $\begin{array}{c}\text { Medium (moderately } \\
\text { controlled by the } \\
\text { state) }\end{array}$ & $\begin{array}{l}\text { Medium but con- } \\
\text { trolled by the state }\end{array}$ & $\begin{array}{c}\text { Rather low in the } \\
\text { 1990s and later even } \\
\text { lower }\end{array}$ \\
\hline $\begin{array}{l}\text { Main decision } \\
\text { making body }\end{array}$ & Municipal council & Municipal council & $\begin{array}{c}\text { Local national com- } \\
\text { mittee }\end{array}$ & Municipal council \\
\hline Main executive body & Magistrate & Mayor & $\begin{array}{c}\text { Chair of the local } \\
\text { national committee } \\
\text { together with board } \\
\text { of the national com- } \\
\text { mittee }\end{array}$ & Mayor \\
\hline $\begin{array}{l}\text { Power relation } \\
\text { between the main } \\
\text { decision making } \\
\text { body and main } \\
\text { executive body }\end{array}$ & $\begin{array}{l}\text { Domination of } \\
\text { magistrate }\end{array}$ & $\begin{array}{l}\text { Domination of } \\
\text { municipal council }\end{array}$ & $\begin{array}{l}\text { Relative equal- } \\
\text { ity with moderately } \\
\text { stronger position of } \\
\text { the chair }\end{array}$ & $\begin{array}{l}\text { Domination of } \\
\text { mayor }\end{array}$ \\
\hline
\end{tabular}

Source: authors (based on relevant legal provisions) 
Table 8: Historical development of the local (self-)government system in the Czech Republic

\begin{tabular}{|c|c|c|c|c|}
\hline & $\begin{array}{l}\text { Habsburg } \\
\text { monarchy }\end{array}$ & $\begin{array}{l}\text { Inter-war } \\
\text { period }\end{array}$ & $\begin{array}{l}\text { Period of } \\
\text { socialism }\end{array}$ & $\begin{array}{c}\text { Period } \\
\text { after } 1989\end{array}$ \\
\hline Centralization & $\begin{array}{l}\text { Relatively decen- } \\
\text { tralized }\end{array}$ & $\begin{array}{c}\text { First decade decen- } \\
\text { tralized, later rather } \\
\text { centralized and } \\
\text { during WWII strictly } \\
\text { centralized }\end{array}$ & Centralized & $\begin{array}{l}\text { First decade rather } \\
\text { decentralized and } \\
\text { later highly decen- } \\
\text { tralized }\end{array}$ \\
\hline $\begin{array}{l}\text { Layers of } \\
\text { sub-national } \\
\text { government }\end{array}$ & 3 & $\begin{array}{l}2 \text { later } 3 \text { with uti- } \\
\text { lization of unified } \\
\text { model (authorities } \\
\text { were responsible } \\
\text { for both self-gov- } \\
\text { ernment and state } \\
\text { administration) }\end{array}$ & $\begin{array}{c}3 \text { with existence of } \\
\text { no self-government } \\
\text { in fact }\end{array}$ & $\begin{array}{l}2 \text { with utilization of } \\
\text { dual model till 2001, } \\
\text { later rather fusion } \\
\text { model }\end{array}$ \\
\hline $\begin{array}{l}\text { Performing state } \\
\text { administration }\end{array}$ & Medium & High & Total & Medium \\
\hline $\begin{array}{l}\text { Fiscal autonomy in } \\
\text { relation to the state }\end{array}$ & Low & Low & None & $\begin{array}{l}\text { Low in the first } \\
\text { decade and later } \\
\text { medium }\end{array}$ \\
\hline $\begin{array}{l}\text { Possibility to } \\
\text { introduce own local } \\
\text { taxes or to modify } \\
\text { their rates }\end{array}$ & Low & Low & None & $\begin{array}{l}\text { Low in the first } \\
\text { decade and later } \\
\text { higher }\end{array}$ \\
\hline Concentration trend & $\begin{array}{l}\text { Increasing number } \\
\text { of municipalities }\end{array}$ & $\begin{array}{l}\text { Increasing number } \\
\text { of municipalities }\end{array}$ & $\begin{array}{c}\text { Obligatory (co- } \\
\text { ordinated by the } \\
\text { state) decreasing of } \\
\text { number of munici- } \\
\text { palities } \\
\end{array}$ & $\begin{array}{c}\text { Increasing number } \\
\text { of municipalities in } \\
\text { the early 1990s and } \\
\text { later stabile number } \\
\text { of them }\end{array}$ \\
\hline Major competences & $\begin{array}{c}\text { Local infrastructure, } \\
\text { local safety and } \\
\text { social security, local } \\
\text { education, } \\
\text { local financial } \\
\text { management }\end{array}$ & $\begin{array}{c}\text { Local infrastructure, } \\
\text { local safety and } \\
\text { social security, local } \\
\text { education } \\
\text { local financial } \\
\text { management }\end{array}$ & $\begin{array}{l}\text { All public issues } \\
\text { that were not } \\
\text { recognized as the } \\
\text { issues that should } \\
\text { be managed / ad- } \\
\text { ministered by some } \\
\text { higher authority }\end{array}$ & $\begin{array}{l}\text { Local infrastructure } \\
\text { and transport, local } \\
\text { safety and social se- } \\
\text { curity, local educa- } \\
\text { tion, protection of } \\
\text { environment, local } \\
\text { financial manage- } \\
\text { ment } \\
\end{array}$ \\
\hline $\begin{array}{l}\text { Degree of } \\
\text { regulation of } \\
\text { competences }\end{array}$ & Low & $\begin{array}{l}\text { Low-medium (mod- } \\
\text { erately controlled } \\
\text { by the state) }\end{array}$ & $\begin{array}{l}\text { Medium but con- } \\
\text { trolled by the state }\end{array}$ & $\begin{array}{c}\text { Low in the 1990s } \\
\text { and later even } \\
\text { lower }\end{array}$ \\
\hline $\begin{array}{l}\text { Main decision } \\
\text { making body }\end{array}$ & Municipal council & Municipal council & $\begin{array}{l}\text { Local national com- } \\
\text { mittee }\end{array}$ & Municipal council \\
\hline Main executive body & Mayor & Municipal board & $\begin{array}{l}\text { Chair of the local } \\
\text { national committee } \\
\text { and board of na- } \\
\text { tional committee }\end{array}$ & $\begin{array}{l}\text { Executive commit- } \\
\text { tee (mayor in the } \\
\text { small municipali- } \\
\text { ties) }\end{array}$ \\
\hline $\begin{array}{l}\text { Power relation } \\
\text { between the main } \\
\text { decision making } \\
\text { body and main } \\
\text { executive body }\end{array}$ & $\begin{array}{l}\text { Domination of } \\
\text { mayor }\end{array}$ & $\begin{array}{l}\text { Domination of } \\
\text { municipal board }\end{array}$ & $\begin{array}{c}\text { Relative equality } \\
\text { with moderately } \\
\text { stronger position of } \\
\text { the chair }\end{array}$ & $\begin{array}{l}\text { Domination of exec- } \\
\text { utive committee (or } \\
\text { mayor in the small } \\
\text { municipalities) }\end{array}$ \\
\hline
\end{tabular}

Source: authors (based on relevant legal provisions) 
Several international classification systems have addressed local (self-) government or related issues since the 1980s but they have either put the CEE countries in a single box or omitted these countries altogether (e.g. Denters Rose 2005; Hesse 1991; John 2001; Page - Goldsmith 1987). If we look, however, at the fairly recent taxonomy produced by Swianiewicz (2014), we find that each of the countries examined in our study falls in a different country group. According to Swianiewicz, Slovakia, like Poland and Hungary, is one of the central European „champions of decentralization. “ The Czech Republic, on the other hand, is grouped together with Estonia and Latvia; these are countries whose local self-government systems are similar to those in the above decentralisation group but whose municipalities have far less financial autonomy and whose local leadership is fairly collective. Similarly, Slovenia, Romania, Croatia and Bulgaria belong in a „Balkan“ group which conforms more closely with a well-known southern European model.

As regards the position of local self-government in the public administration of the examined countries, it must be kept in mind that all these countries have adopted the European Charter of Local Self-government into their legal systems. Nevertheless, while Slovenia has expressed no reservations about the Charter's content and Slovakia has gradually implemented all its provisions, the Czech Republic has explicitly stated a number of reservations and implemented only limited provisions.

Turning again to Slovenia, the complexity of the country's local self-government system has clearly increased over time as a result of (over-)regulation. While the structure of government has been streamlined so that the municipal level is the only sub-national level, the total number of municipalities has increased dramatically since the beginning of the 1990s. At the same time, the central government has established its own system of local offices to handle state tasks at the sub-national level, thereby removing those tasks entirely from the list of municipalities' powers. In this sense, the role of Slovenian municipalities has been reduced, and their autonomy is now strictly limited to certain financial and management issues.

Concerning the Slovak local self-government system, the last 20 years have seen the development of a highly decentralised system known for its low level of efficiency. Local governments are quite powerful and their fiscal autonomy is also relatively high. Even so, if we compare these units to the strong local governments in places such as Scandinavia, the average Slovak municipality is very small (Buček 2005). This is despite the fact that the fragmentation wave that hit Slovakia after 1990 was much weaker than comparable waves in the Czech Republic and Slovenia.

Within the Czech Republic, the development of local (self-)government resembles the Slovak experience. Surprisingly, however, given the existence of a common state with Slovakia (Czechoslovakia) between 1918 and 1992, there 
are significant differences between the current local self-government systems in the two countries. Though some links can be drawn between the present and the inter-war period, these differences also recall the divergence between the Austrian and Hungarian parts of the Habsburg monarchy.

In sum, as the data in the comparative tables shows, the Slovenian local (self-) government system has not developed significantly since the end of the 19th century. This absence of substantial change should not be explained, however, as simply a failure to evolve. Rather, we may make sense of it using the concepts of early path dependence and initial outcome path dependence. Similarly, when we look to the current local self-government systems in the Czech Republic and Slovakia, we find that the systems in the two countries differ markedly from each other as well as from their Slovenian counterpart. The current state of all three local (self-)government systems is also different from their situation in the past. Still, there are clear links between their institutional set-up after 1990 and in eras before World War II, especially the inter-war years.

\section{Concluding remarks}

In spite of their international achievements, including integration into the European Union in 2004, and their relatively successful transition, each of the examined countries must deal with the legacies of communism. The latter include a lack of transparency, corruption, a low level of political accountability and inefficient public service delivery. Nevertheless, a comparison of institutions in the local (self-)government systems in these countries shows that they are generally more influenced by the outcomes of the inter-war period (and to a limited extent, the Habsburg period) than those of the socialist era (see also Bakoš et al. 2015). Revisiting our assumptions, we can make the following statements:

1) The development of local self-government systems in all these countries shows recognisable path dependence.

2) To some extent, the development of local self-government systems after 1990 was outcome-dependent while the process during the socialist period was quite state-dependent.

3) The post-1990 development of local self-government systems in these countries was both early path-dependent (in terms of the inter-war years) and initial outcome-dependent (in terms of the Habsburg monarchy era). Ultimately, however, the early path dependence prevailed.

At the same time, the limited consistency in the compared criteria across the selected countries may also suggest alternative trends. From this standpoint, a high level of centralisation was typical during the socialist period in the Czech Republic and Slovakia but not in Slovenian territory. Paradoxically, centralisa- 
tion became a reality in Slovenia after 1990, a development that recalled the local (self-)government system used in the country before World War II.

In fact, while the Czech Republic, Slovakia and Slovenia are all labelled CEE countries, they differ significantly when it comes to their past and present local (self-)government systems. In this context, this study confirms the conclusions of Swianiewicz (2014). On the other hand, the existence of recognisable path dependence in all three cases reinforces the conclusions of Bakoš, Soukopová and Selešovský (2015).

\section{References}

Act no. 75/1919 Coll. A. D. on Local Elections.

Act no. 76/1919 Coll. A. D. on the Amendment of Current Municipal Establishments and Urban Statuses in the Czechoslovak Republic.

Act No. 13/1954 Coll. on National Committees.

Act No. 65/1960 Coll. on National Committees.

Act No. 369/1990 Coll. on Municipal Establishment.

Act on Local Self-Government. Uradni list Republike Slovenije št. 94/2007.

Arthur, Brian (1994): Increasing Returns and Path Dependence in the Economy, Ann Arbor.

Bakoš, Eduard - Soukopová, Jana - Selešovský, Jan (2015): The Historical Roots of Local Self-Government in Czech and Slovak Republics. Lex Localis - Journal of Local Self-Government 13 (1): 1-19.

Balík, Stanislav (2003): Vývoj obecního volebního práva od roku 1848 do současnosti, in Balík, S., ed., Komunální volby v České republice v roce 2002, Masarykova univerzita, Brno.

Balík, Stanislav (2009): Komunální politika: Obce, aktéři a cíle místní politiky, Grada Publishing, Praha.

Berengaut, Julian - Lopez-Claros, Augusto (1998): Overview of Recent Macroeconomic and Structural Adjustment Policies, in Berengaut, J. et al., eds., The Baltic Countries. From Economic Stabilization to EU Accession, IMF Occasional Paper 173. 2-8, International Monetary Fund, Washington.

Boschma, Ron - Martin, Ronald, eds. (2010): The Handbook of Evolutionary Economic Geography, Edward Elgar, Cheltenham.

Buček, Ján (2005): Slovakia, in Van Kempen, R. - Vermeulen, M. - Baan, A., eds., Urban Issues and Urban Policies in the New EU Countries. 79-108, Ashgate, Aldershot.

Buček, Ján (2006): The position of local self-government after the main phase of public administration reform in Slovakia. Acta Geographica Universitatis Comenianae 48: 167-178.

Buček, Milan - Nemec, Juraj (2012): Local Government in Slovakia, in Moreno, A.-M., ed., Local Government in the Member States of the European Union: A Comparative Legal Perspective. 555-576, Instituto Nacional de Administración Pública, Madrid. 
Constitution of the Republic of Slovenia. Ljubljana: Uradni list Republike Slovenije, 2001.

Constitutional Act No. 460/1992 Coll. Constitution of the Slovak Republic.

Crouch, Collin - Farrell, Henry (2004): Breaking the Path of Institutional Development? Alternatives to the New Determinism. Rationality and Society 16 (1): 5-43.

Čapková, Soňa (2010): Slovakia: Local Government: Establishing Democracy at the Grassroots, in Loughlin, J. - Hendriks, F. - Lidström, A., eds., Oxford Handbook of Local and Regional Democracy in Europe. 552-576, Oxford University Press, New York.

Čavojec, Jozef - Sloboda, Dušan (2005): Fiškálna decentralizácia a obce. Konzervatívny inštitút M. R. Štefánika, Bratislava.

Čechák, Vladimír - Lacina, Karel (2001): Vývoj systémů veřejné správy, Professional Publishing, Praha.

Český statistický úřad (2006): Historický lexikon obcí České republiky 1869-2005, I., Český statistický úřad, Praha.

Čmejrek, Jaroslav - Bubeníček, Václav - Čopík, Jan (2010): Demokracie v lokálním politickém prostoru. Grada Publishing, Praha.

Čopík, Jan (2014): Proměny a kontinuita české komunální politiky. Územní samospráva v nové době (1850-2010), Díl I - do roku 1945, Scriptorium, Praha.

David, Paul A. (2001): Path Dependence, Its Critics and the Quest for "Historical Economics, ${ }^{\text {in }}$ Garrouste, P. - loannides, S., eds., Evolution and Path Dependence in Economic Ideas: Past and Present. 15-40, Edward Elgar, Cheltenham.

Denters, Bas - Rose, Lawrence E. (2005): Towards Local Governance?, in Denters, B. - Rose, L. E., eds., Comparing Local Governance: Trends and Developments. 46-62, Palgrave, Houndmills.

Garrouste, Pierre - loannides, Stavros., eds. (2001): Evolution and Path Dependence in Economic Ideas: Past and Present, Edward Elgar, Cheltenham.

Grafenauer, Božo (2000): Lokalna samouprava na Slovenskem: teritorialno-organizacijske structure, Pravna fakulteta, Maribor.

Heinelt, Hubert - Hlepas, Nikos (2006): Typologies of Local Government Systems, in Bäck, H. Heinelt, H. - Magnier, A., eds., The European Mayor. Political Leaders in The Changing Context of Local Democracy. VS Verlag für Sozialwissenschaften, Wiesbaden.

Hesse, Joachim Jens, ed. (1991): Local Government and Urban Affairs in International Perspective: Analyses of Twenty Western Industrialised Countries, Nomos, Baden-Baden.

Illner, Michael (2010): The Voluntary Union of Municipalities: Voluntary Bottom-up Territorial Consolidation in Czech Republic?, in Swianiewicz, P., ed., Territorial Consolidation Reforms in Europe. OSI/LGI, Budapest.

John, Peter (2001): Local Governance in Western Europe, Sage, New York.

Jüptner, Petr (2008): Local lists in the Czech Republic, in Reiser, M. - Holtmann, E., eds., Farewell to the party model? Independent local lists in East and West European countries. 21-37, VS Verlag für Sozialwissenschaften, Wiesbaden.

Jüptner, Petr (2011): Le système local Tchèque: un modèlle a l,écart des tendances européennes? Revue de Institut du Monde et du Developpement 1 (2): 103-118. 
Jüptner, Petr (2017): Debating directly elected mayors in the Czech Republic: political games and missing expertise?, in Sweeting, D., ed., Directly elected mayors in urban governance: impact and practice, 201-218, Policy Press, Bristol.

Kay, Adrian (2005): A Critique of the Use of Path Dependency in Policy Studies. Public Administration 83 (3): 553-571.

Klimovský, Daniel (2009): Politics and its impact on the reform processes: The case of public administration reform in Slovakia (1989-2006), in Musil, J., ed., Space and Historical Time as Dimensions of Social Change, 45-64, Charles University, Praha.

Klimovský, Daniel (2010): Territorial consolidation and intercommunal cooperation at the local level in the Slovak Republic, in Swianiewicz, P., ed., Territorial Consolidation Reforms in Europe, 237-253, OSI/LGI, Budapest.

Klimovský, Daniel (2013): Local Public Reforms in Central and Eastern Europe: Agendas for the future, in lancu, D.-C., ed., Local Reforms in Transition Democracies, 11-26, Institutul European, Iaşi.

Klimovský, Daniel (2014): Základy verejnej správy, 2nd edition, Wolters Kluwer, Bratislava.

Kling, Jaroslav - Nižňanský, Viktor (2003): Public Administration, in Kollár, M. - Mesežnikov, G. - Nicholson, T., eds. (2003): Slovakia 2002: A Global Report on the State of Society,183-200, Inštitút pre verejné otázky, Bratislava.

Kopřiva, Radek - Čopík Jan - Čmejrek Jaroslav (2017): Mechanismy rozhodování o investičních záměrech a rozpočtech obcí. Sociológia 49 (5): 482-506.

Kruntorádová, Ilona (2013): Regional patron as a phenomenon of interest representation, in Pinterič, Uroš - Prijon, Lea, eds. (2013): Selected issues of administrative reality, 55-72, Fakulteta za organizacijske študije, Novo mesto.

Koudelka, Zdeněk (2007): Samospráva. Linde, Praha.

Kováč, Dušan (1998): Dejiny Slovenska. Nakladatelství Lidové noviny, Praha.

Liebowitz, Stan J. - Margolis, Stephen E. (1995): Path dependence, lock-in, and history. Journal of Law, Economics, and Organization 11 (1): 205-226.

Manca, Stanislav J. (2003): Reálny život je vel'akrát trochu iný: Rozhovor s V. Nižňanským. Verejná správa a spoločnost' 58 (10): 2-4.

Page, Edward C. - Goldsmith, Michael (1987): Central and Local Government Relations: A Comparative Analysis of Western European Unitary States, Sage.

Page, Scott E. (2006): Path Dependence. Quarterly Journal of Political Science 1: 87-115.

Pierson, Paul (2000): Path Dependence, Increasing Returns, and the Study of Politics. American Political Science Review 94 (2): 251-267.

Pierson, Paul (2004): Politics in Time: History, Institutions, and Social Analysis, Princeton University Press.

Postránecký, Josef (2004): Reforma veřejné správy v České republice, in Grospič, J. - Vostrá, L., eds., Reforma veřejné správy $v$ teorii a praxi. Aleš Čeněk, Plzeň.

Rupnik, Jacques (2000): In Search of East-Central Europe: Ten Years After, in Gardner, H., ed., Central and Southeastern Europe in Transition: Perspectives on Success and Failure Since 1989. 5-19, Westport, Praeger. 
Schelle, Karel (1991a): Vývoj správy v předválečném Československu (1918 - 1927). I. část, Masarykova univerzita, Brno.

Schelle, Karel (1991b): Vývoj správy v předválečném Československu (1928 - 1939). II. část, Masarykova univerzita, Brno.

Schelle, Karel (2005): Vývoj veřejné správy v letech 1848-1990, EUROLEX Bohemia, Praha.

Sokolovský, Leon (1995a): Prehl'ad dejín verejnej správy na území Slovenska. II. čast'. Od roku 1526 do roku 1848, Metodické centrum mesta Bratislavy, Bratislava.

Sokolovský, Leon (1995b): Prehlad dejín verejnej správy na území Slovenska. III. čast́. Od roku 1848 do roku 1918, Metodické centrum mesta Bratislavy, Bratislava.

Swianiewicz, Pawel (2014): An Empirical Typology of Local Government Systems in Eastern Europe. Local Government Studies 40 (2): 292-311.

Šmidovnik, Janez (1995): Lokalna samouprava, Cankarjeva založba, Ljubljana.

Táborský, Edward (1951): Local Government in Czechoslovakia (1918-1948). American Slavic and East European Review 10 (3): 202-215.

United Nations (2000): Professionalism and Ethics in the Public Service: Issues and Practices in Selected Regions, United Nations, New York.

Vlaj, Stane (2006): Lokalna samouprava: teorija in praksa, Fakulteta za upravo, Ljubljana.

Daniel Klimovský works at Department of Political Science, Faculty of Arts, Comenius University, Slovakia, daniel.klimovsky@uniba.sk.

Uroš Pinterič is a Professor of Political Science, Department of Political Science, Faculty of Arts, Trnava University, Slovakia, Jean Monnet Chair, Faculty of Organisational Studies, Slovenia, uros.pinteric@gmail.com,

Petr Jüptner works as a Director of the Institute of Political Studies, Faculty of Social Sciences, Charles University, Prague, the Czech Republic, petr.juptner@fsv.cuni.cz. 